\title{
RESEARCH
}

\section{Long-range Mapping and Construction of a YAC Contig within the Cat Eye Syndrome Critical Region}

\author{
Heather E. McDermid, ${ }^{1,5}$ Kerry E. McTaggart, ${ }^{1}$ M. Ali Riazi, ${ }^{1}$ \\ Thomas J. Hudson, ${ }^{2,3}$ Marcia L. Budarf, ${ }^{4}$ Beverly S. Emanuel, ${ }^{4}$ and \\ Callum J. Bell ${ }^{4}$
}

${ }^{1}$ Department of Biological Sciences, University of Alberta, Edmonton, Alberta, Canada, T6C 2E9; ${ }^{2}$ Center for Genome Research, Whitehead Institute/MIT, Cambridge, Massachusetts 02139; ${ }^{3}$ Montreal General Hospital, Montreal, Quebec, Canada, H3G 1A4; ${ }^{4}$ Children's Hospital of Philadelphia, Division of Human Genetics and Molecular Biology, The Human Genome Center for Chromosome 22, Philadelphia, Pennsylvania 19104

Cat eye syndrome (CES) is typically associated with a supernumerary bisatellited marker chromosome derived from human chromosome 22pter to 22ql1.2. The region of 22q duplicated in the typical CES marker chromosome extends between the centromere and locus D22S36. We have constructed a long-range restriction map of this region using pulsed-field gel electrophoresis and probes to 10 loci (11 probes). The map covers $\sim 3.6 \mathrm{Mb}$. We have also used 15 loci to construct a yeast artificial chromosome contig, which encompasses about half of the region critical to the production of the CES phenotype (centromere to D22S57). Thus, the CES critical region has been mapped and a substantial portion of it cloned in preparation for the isolation of genes in this region.

Cat eye syndrome (CES) is a highly variable disorder generally characterized by ocular coloboma, anal atresia, preauricular skin pits and tags, defects of the heart and urogenital system, dysmorphic features, and mild mental retardation (Schinzel et al. 1981). It is usually associated with a supernumerary, bisatellited marker chromosome that is derived from duplicated regions of 22pter-22q11.2, resulting in a total of four copies of this segment (McDermid et al. 1986a). Previously, we have compared the marker chromosomes of $10 \mathrm{CES}$ patients and defined the smallest region of duplication overlap, or critical region, to lie between the centromere and D22S36 (Mears et al. 1994). The parm, although also present in four copies, is not considered to play a role in this syndrome as it is believed to carry only ribosomal genes found on other acrocentric chromosomes. Additionally, CES can also be associated with interstitial duplications that do not involve 22p (Knoll et al. 1995; Reiss et al. 1985). The placement of the CES critical region proximal to D22S36 also separates it from that of the DiGeorge/velocardiofacial/conotruncal heart

${ }^{5}$ Corresponding author.

E-MAlL hmcdermi@gpu.srv.ualberta.ca; FAX (403) 492-9234. defect complex of syndromes associated with a deletion of 22q11.2, because D22S36 is deleted in some but not all of these patients (Driscoll et al. 1992).

In order to understand CES at the molecular level, we have produced a long-range restriction map of the region duplicated in the typical CES marker chromosome, spanning from the centromere to D22S36. This allowed us to estimate the maximum size of the region to be $-3.6 \mathrm{Mb}$. A recently studied CES patient, whose unusual marker chromosome redefines the critical region as proximal to D22S57 (Mears et al. 1995), further reduces the region to $\sim 1.9 \mathrm{Mb}$. In addition, the construction of a yeast artificial chromosome (YAC) contig containing about half of the region between the centromere and D22S181 provides the first step toward cloning the genes involved in the production of the CES phenotype.

\section{RESULTS}

Probes

Probes were originally mapped to the CES region using a somatic cell hybrid panel that subdivides 
chromosome 22 into 24 unique regions or bins (Budarf et al. 1996). A list of probes, their bin assignments, and their sources is given in Table 1. Only 11 of these probes, representing 10 loci, were suitable for pulsed-field gel electrophoresis (PFGE) analysis (marked with an asterisk).

The D22S50, F8VWFL, and D22S543 loci could not be ordered by PFGE and YAC analysis, but were found to be in an overlapping set of cosmids isolated from the LL22NC03 library. D22S50 identified cosmids 80D1, 104F4, and 123D11. F8VWFL also identified these three cosmids as well as $107 \mathrm{C} 11$. D22S543 was used as a probe against a Southern blot containing these four cosmids and hybridized only to 107C11. All three probes hybridized to different-sized HindIII fragments and therefore are distinct loci. These results indicate that F8VWFL clone used lies between D22S50 and D22S543, although the orientation of the three on the chromosome cannot be determined.

\section{PFGE Map}

The PFGE fragment sizes for each of 11 probes representing 10 loci were determined for six enzymes: NotI, NruI, AscI, BsiWI, SgrAI, and MluI
(Fig. 1). The sizes represent the average of several independent experiments for most loci, using DNA from numerous different lymphoblastoid cell lines and fibroblast strains. Multiple fragment sizes for a locus usually indicates the presence of partial enzyme digestion, presumably attributable to varying degrees of methylation at these methylation-sensitive enzyme sites. This is typical for PFGE, as is fragment size pattern variation between individuals. Evidence that multiple fragments represented partial digestion attributable to methylation rather than polymorphism included cell-to-cell variation in intensity between the multiple fragments and changes in fragment pattern when cells were grown in the presence of the demethylating agent 5-azacytidine. For instance, the DNA of most cell lines showed NotI fragments of 430 and $530 \mathrm{~kb}$ when probed with D22S9, D22S50, or D22S795b. With GM02325, the 430-kb fragment was much more intense, whereas with GM03657 the fragments were of equal intensity, which would not be expected if the lines were heterozygotes for a polymorphism (data not shown). However, with GM03657 cells treated with 5-azacytidine, the $530-\mathrm{kb}$ fragment was almost undetectable, because presumably the NotI sites flanking the 430 -

Table 1. Probes Mapped to the CES Critical Region

\begin{tabular}{llll}
\hline Locus & Bin $^{\text {a }}$ & Probe & Source and reference \\
\hline D22Z2 & n.d. & 22/1 & McDermid; McDermid et al. 1986b \\
*D22S458 & 1.1 & N38F3 & Xie/Dumanski; Xie et al. 1994 \\
*D22S795 & 1.1 & LN63a and b & Budarf; this paper \\
D22S543 & n.d. & pH863 & Hudson; Hudson et al. 1994 \\
*D22S50 & 1.1 & pH74 & Budarf; Budarf et al. 1991 \\
D22S601 & 1.1 & pB1124 & Hudson; Hudson et al. 1994 \\
F8VWFL & 1.1 & clone II & ATCC; Mancuso et al. 1991 \\
*D22S9 & 1.1 & p22/34 & McDermid; McDermid et al. 1986a \\
D22S24 & 1.1 & W21G & Rouleau; Rouleau et al. 1989 \\
ICKVP3 & 1.1 & M120-12 & ATCC; Lotscher et al. 1986 \\
*D22S789 & 1.1 & LN44 & Budarf; this paper \\
*D22S43 & 1.2 & pH32 & McDermid; Budarf et al. 1991 \\
*ATP6E & 1.2 & XEN61,DD8 & Lipinski; Baud et al. 1994 \\
*D22S57 & 2 & pH98 & Budarf; Budarf et al. 1991 \\
*D22S181 & NB17 & Zwarthoff; Lekanne Deprez et al. 1991 \\
*D22S36 & pH11 & McDermid; Budarf et al. 1991 \\
\hline Probe mapped outside the CES critical region & \\
\hline & &
\end{tabular}


LONG-RANGE MAP AND YAC CONTIG FOR CAT EYE SYNDROME

\begin{tabular}{|c|c|c|c|c|c|c|}
\hline Probe & Notl & Nrul & Ascl & BsiwI & SgrAl & Mlul. \\
\hline D22S458 & $\begin{array}{l}870+1000 \\
+1250\end{array}$ & - & - & 2500 & $500+720$ & $\begin{array}{l}1400+1600 \\
1800+2000\end{array}$ \\
\hline $\begin{array}{l}\text { D22S795: } \\
\text { LN63a }\end{array}$ & $\begin{array}{l}870+1000 \\
+1250 \\
\end{array}$ & $\begin{array}{l}490+1000 \\
+1200\end{array}$ & $\begin{array}{l}1300+1550 \\
+2450\end{array}$ & $520+1100$ & $\begin{array}{l}950+1150 \\
+1500\end{array}$ & - \\
\hline LN63b & $430+530$ & - & - & - & $\begin{array}{l}950+1150 \\
+1500\end{array}$ & - \\
\hline D22S50 & $430+530$ & $\mid \begin{array}{l}490+1000 \\
+1200\end{array}$ & $\begin{array}{l}1300+1550 \\
+2450\end{array}$ & $520+1100$ & $\begin{array}{l}950+1150 \\
+1500\end{array}$ & - \\
\hline D22S9 & $430+530$ & $\begin{array}{l}340+500 \\
+1000 \\
+1200\end{array}$ & $\begin{array}{l}270+1550 \\
+2450\end{array}$ & $620+1100$ & $\begin{array}{l}950+1150 \\
+1500\end{array}$ & $\begin{array}{l}1400+1600 \\
1800+2000\end{array}$ \\
\hline D22S789 & $100+530$ & - & - & & $\begin{array}{l}950+1150 \\
+1500\end{array}$ & - \\
\hline D22S43 & $220+630$ & $\begin{array}{l}170+500 \\
+1200\end{array}$ & $\begin{array}{l}280+880 \\
+2450\end{array}$ & $620+1100$ & $\begin{array}{l}190+530 \\
+1150+1500\end{array}$ & $\begin{array}{l}250+450 \\
1800+2000\end{array}$ \\
\hline $\begin{array}{l}\text { ATP6E/ } \\
\text { D22S57 }\end{array}$ & $410+630$ & $\begin{array}{l}730+1550 \\
1700+1900\end{array} \mid$ & $\begin{array}{l}600+880 \\
+2450\end{array}$ & $600+800$ & $\begin{array}{l}340+530 \\
+1500 \\
\end{array}$ & $\begin{array}{l}200+450 \\
+2000 \\
\end{array}$ \\
\hline D22S181 & $\begin{array}{l}650+840 \\
+1100\end{array}$ & $\begin{array}{l}730+1550 \\
1700+1900\end{array}$ & $\begin{array}{l}600+880 \\
+2450\end{array}$ & $600+800$ & 230 & $\begin{array}{l}280+410+ \\
480+1000\end{array}$ \\
\hline D22S36 & $\begin{array}{l}70+180 \\
220\end{array}$ & $\begin{array}{l}650+1550 \\
1700+1900\end{array}$ & 220 & $\begin{array}{l}390+750 \\
+880\end{array}$ & $130+750$ & $\begin{array}{l}160+930 \\
+1400\end{array}$ \\
\hline
\end{tabular}

$\begin{array}{lllllll}\text { D22S111 } 230 & 440+540 & 850+930 & 230 & 270+510 & 500+1500\end{array}$

Figure 1 Average PFGE fragment sizes for loci in the CES region of 22q11.2. Fragment sizes in kilobases for six enzymes are given for 11 probes representing 10 loci. Multiple sizes at a locus indicate partial digestion, presumably attributable to variable methylation. One particular DNA sample may not show all fragment sizes listed, and some infrequent fragments have not been included. Regions of overlap between loci, as judged by superimposing autoradiograms, are outlined in boxes. LN63a and b at locus D22S795 are probes on either side of the LN63 Notl site. ATP6E gave a pattern identical to D22S57 with additional unlisted faint bands attributable to homology to other loci. Dashes indicate analysis was not done. partial digestion differences between cell lines often aided in determining whether two probes mapped to the same large fragment or two comigrating fragments (Fig. 2; see below). Several probes (LN63a, D22S50, ATP6E, and D22S36) showed additional faint fragments attributable to crosshybridization to related loci, and these were not included in Figure 1.

Most of the CES critical region (N38F3 to D22S57) is contained within a $2000-\mathrm{kb} M l u \mathrm{I}$ fragment produced by partial digestion (Fig. 2). The most centromeric probe, N38F3, represents the second step in a cosmid walk (Xie et al. 1994) from a clone (N65D4) containing chromosome 22-specific alphasatellite sequences. Therefore this probe can be considered pericentromeric and anchors the map to the top of the critical region. The three cell lines in Figure 2 (lanes 1-3) were chosen to show the extent of the differences in partial digestion patterns and how these were used to construct the map. Thus, lane 2 shows an $1800-\mathrm{kb}$ partially digested $\mathrm{MluI}$ fragment with probes N38F3, D22S9, and D22S43, and a 200$\mathrm{kb}$ fragment with D22S57, indicating that $M l u$ I sites 1,3 , and 4 are digested in this DNA sample. Lane 3 shows a 1600 $\mathrm{kb}$ fragment for N38F3 and D22S9, and a $450-\mathrm{kb}$ fragment for D22S43 and D22S57, indicating that $M l u$ I sites 1,2 , and 4 are digested. In lane 1, fragments of 1600 and 2000 are seen with N38F3 and D22S9. D22S43 hybridizes to the 2000-kb fragment as well as fragments of 250 and 450, whereas D22S57 shows fragments of 200, 450, and $2000 \mathrm{~kb}$ (small fragments were sized on blots optimized for this size range). This indicates that all four $M l u I$ sites were digested, but sites 2 and 3 were only partially digested. GM7511A fibroblasts showed a dense 1600 -kb fragment but a weak $2000-\mathrm{kb}$ fragment when probed with 


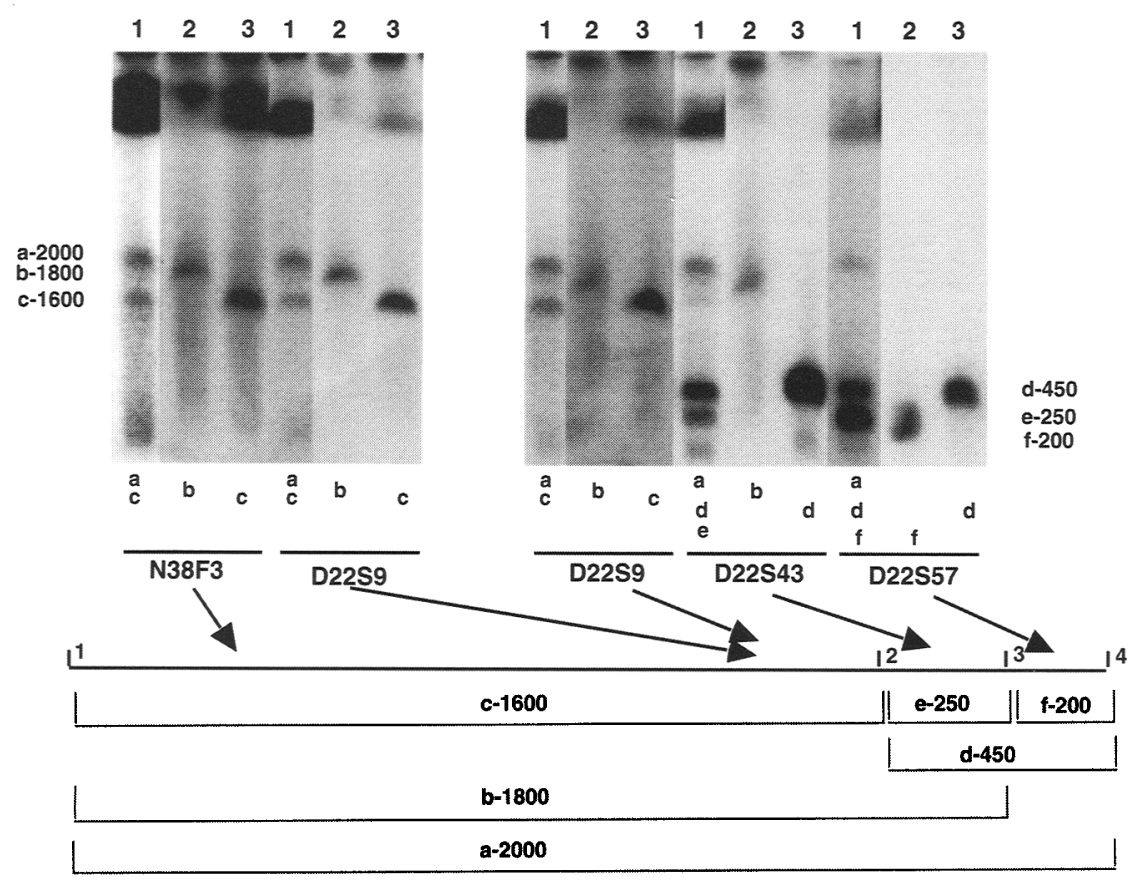

Figure 2 Mlul-digested fragments span from N38F3 to D22S57. DNA from various individuals with no rearrangement in $22 \mathrm{q} 11.2$ were digested with Mlul, electrophoresed in a CHEF DRII apparatus in two $0.8 \%$ agarose gels run together at $75 \mathrm{~V}$ for $93 \mathrm{hr}$ with a ramped switch time of 550-850 sec in $1 \times$ Tris-acetate buffer (TAE), and transferred to a nylon membrane. The two blots with identical lanes were sequentially probed with N38F3 (a) and D22S9 (b) for the first blot and with D22S9 (c), D22S43 (d), and D22S57 (e) for the second blot. The fragments present are indicated below each lane by letter code. A partially digested fragment of $\sim 2000 \mathrm{~kb}$ was identified by each probe in lane 1, representing the maximum distance between $\mathrm{N} 38 \mathrm{~F} 3$ and D22S57. As shown in the map below the autoradiographs, this 2000-kb band has two internal Mlul sites ( 2 and 3 ), which subdivide it into fragments of 1600,250 , and $200 \mathrm{~kb}$. Small fragments (200, 250, and 450) were sized on other blots optimized for this resolution range. The three different lanes show different combinations of these Mlul sites, as described in the text: (Lane 1) JT; (lane 2) TC32; (lane 3) BL-2.

D22S9, whereas the opposite pattern was seen with the lymphoblastoid cell line AJ, arguing against this variation in fragment size originating from a polymorphism (data not shown). Thus, using three cell lines that show different partial digestion patterns, the interval between N38F3 and D22S57 was shown to span a maximum of $2000 \mathrm{~kb}$. An additional MluI site not seen in these cell lines but evident in others is mapped below.

A PFGE map of the region is shown in Figure 3. Most individual enzyme restriction maps could be constructed independently using partial digestion fragments as shown in Figure 2. The restriction maps for individual enzymes were confirmed and aligned by a series of double di- gests, which are represented on the map as dotted lines between two different enzyme sites. Each dotted line indicates an experimentally confirmed fragment flanked by the two sites at either end of the line. The map includes the entire region normally duplicated in CES from the pericentromeric region to D22S36. The maximal size of this region is $\sim 3.6 \mathrm{Mb}$. The critical region between D22S458, a pericentromeric probe (Xie et al. 1994), and D22S57 spans $\sim 1.9 \mathrm{Mb}$.

\section{YAC Contig}

The probes in Table 1 for which there were no available sequence-tagged sites (STSs) were partially sequenced, and STSs were produced in preparation for the screening of YAC libraries. The primer sequences or accession numbers for these STSs are given in the Methods section. STSs corresponding to loci mapped to the CES region were used to screen the original CEPH YAC library (Albertsen et al. 1990) and the CEPH megaYAC library (Chumakov et al. 1992) with average insert sizes of 470 and $900 \mathrm{~kb}$, respectively. A YAC contig containing 15 loci and 15 YACs was assembled, using marker order obtained from the PFGE map as a constraint (YACs are listed in Table 2). Additionally, the data were analyzed with a contig assembly program independent of the PFGE data (Bell et al. 1995) that uses a simulated annealing algorithm. These two approaches were in complete agreement, with the exception of the region containing D22Z2 and N38F3. In this region of the contig, the data lacked sufficient information to order these probes, and therefore the assembly program switched them randomly. An STS was not produced for D22Z2, a probe that contains chromosome 22-specific alpha-satellite sequences (McDermid et al. 1986b). Assignment of this probe to YAC $745 \mathrm{G} 7$ was ac- 
LONG-RANGE MAP AND YAC CONIIG FOR CAT EYE SYNDROME
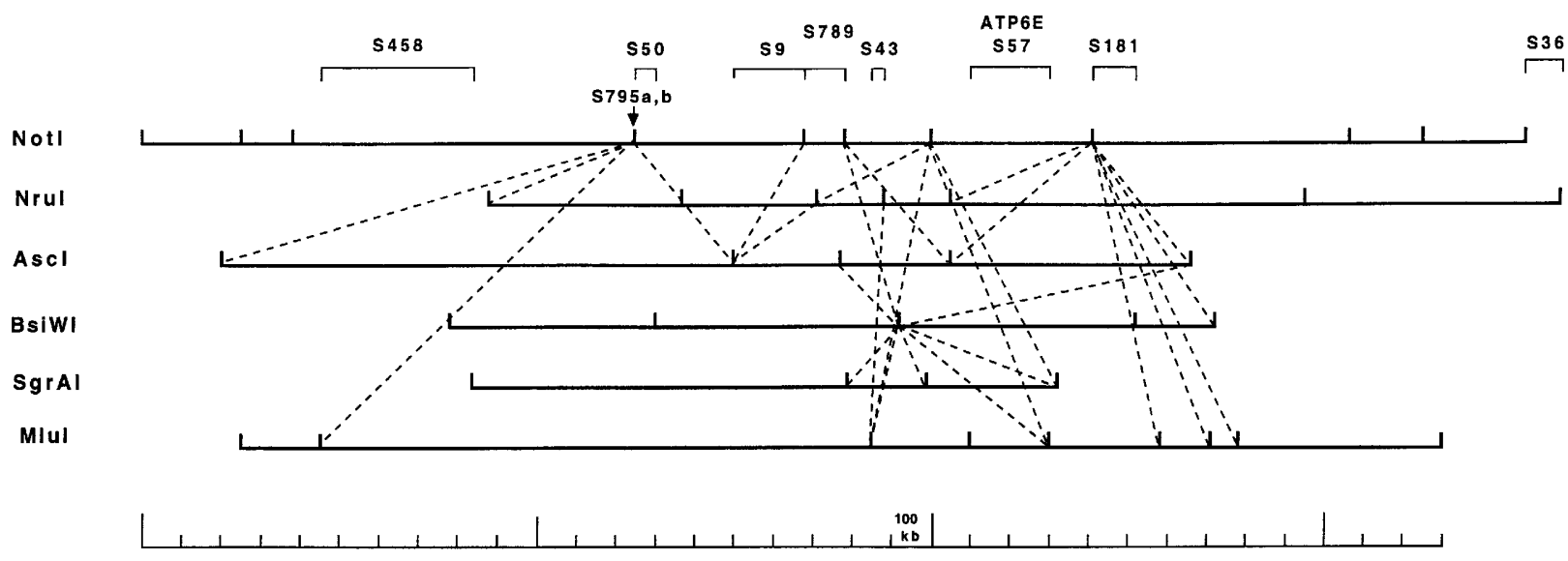

Figure 3 PFGE map of the CES region of 22q11.2. This map is based on the alignment of the fragments for each locus by analysis of a series of two enzyme digestions. The double-digestion fragments that have been confirmed experimentally are indicated by dashed lines connecting the two sites involved. The location of loci used in the production of the map are indicated by square brackets above the restriction fragments. Loci names are given without the preceding D22 designation. D22S795a,b (S795a,b) contains the Notl site (arrow). The maximum size of the mapped region is $\sim 3.6 \mathrm{Mb}$.

complished by Southern blot hybridization to YAC DNA. To verify the YAC contig, the PCR results were confirmed by hybridization on Southern blots.

To characterize these YACs further, each was subjected to PFGE and visualized for sizing by probing a Southern blot with radiolabeled total human DNA to identify the YACs (Table 2). YACs 745G7, 800A4, and 925G12 all showed multiple bands in a single isolate of each YAC. YAC 745G7 contained four bands $(640,860,980$, and 1200 $\mathrm{kb}$ ), all of which hybridized to D22Z2, a probe

\begin{tabular}{|c|c|c|}
\hline YAC name & Size $(\mathbf{k b})$ & FISH results \\
\hline $745 G 7$ & $640 / 860 / 980 / 1200^{a}$ & 22 (weak) $+C$ (strong) $+D$ (weak) \\
\hline 723B6 & 720 & 22 (weak) +2 (strong) $+C / E$ (weak) $+D$ (weak) \\
\hline 715A9 & 1600 & $22+B / C$ \\
\hline $776 \mathrm{H} 2$ & 1280 & 22 (strong) +2 (strong) $+B$ (weak) $+D$ (weak) \\
\hline 734B10 & 1000 & 22 (strong) +21 (weak) \\
\hline $829 \mathrm{E} 11$ & 950 & $22+B / C^{-}$ \\
\hline 878D3 & 1010 & 22 (weak) + A (strong) \\
\hline 829D11 & 980 & $22+B / C$ \\
\hline $800 \mathrm{~A} 4$ & $560 / 1600^{b}$ & chimeric \\
\hline $100 \mathrm{G} 7$ & 380 & 22 \\
\hline $925 \mathrm{G} 12$ & $450 / 570 / 690 / 790^{c}$ & $22+C$ \\
\hline $803 G 9$ & 200 or $580^{d}$ & 22 \\
\hline $891 F 12$ & 620 & 22 (weak) $+B / C+D$ \\
\hline $891 C 8$ & 160 & 22 (very weak) + D \\
\hline $422 \mathrm{G} 4$ & 230 & 22 \\
\hline \multicolumn{3}{|c|}{$\begin{array}{l}\text { aAll four YAC bands were present in one isolate, all bands hybridized to D22Z2. } \\
\text { both YAC bands were present in one isolate, both bands hybridized to D22S9. Four independent isolates gave the same pattern } \\
\text { cAll YAC bands were present in one isolate, all bands hybridized to D22S9. } \\
\text { dEach YAC band was present in a different isolate, both bands hybridized to D22S9. The 200-kb YAC was isolated independently } \\
\text { four times, the } 580-\mathrm{kb} \text { YAC was isolated twice. Subsequent analysis of further independent isolates revealed YACs of } 320 \mathrm{~kb} \text { (once) } \\
610 \mathrm{~kb} \text { (eight times), and } 750 \mathrm{~kb} \text { (once). These were not analyzed further. }\end{array}$} \\
\hline
\end{tabular}


that hybridized to no other YAC. Bands from 800A4 (560 and $1600 \mathrm{~kb}$ ) and 925G12 (450, 570, 690 , and $790 \mathrm{~kb}$ ) all hybridized to D22S9. These results suggest the presence of a series of deletions of the original YAC rather than multiple independent YACs. YAC 803G9 contained only one band, but this varied in size depending on the isolate. However, both the 200- and 580-kb YACs hybridized to D22S9, suggesting that this YAC was also unstable.

Fluorescence in situ hybridization (FISH) was performed on each YAC to test for chimerism (Table 2). Only three YACs $(100 \mathrm{G} 7,803 \mathrm{G} 9$, and 422G4) gave fluorescent signal on only chromosome 22 . Four of the 15 YACs mapped to three or four different chromosomes. To confirm chimerism for 734B10, which gave a strong fluorescent signal on chromosome 22 but a weak signal on the other G-group chromosome (presumably chromosome 21), end clones were produced by inverse-PCR. End clone 734B10HU hybridized to $734 \mathrm{~B} 10$ and the nonchimeric $100 \mathrm{G} 7$ as expected for the distal end of the YAC. End clone 734B10T hybridized to chromosome 21 on a monochromosomal hybrid panel, confirming the FISH results (data not shown).

To place the YACs on the PFGE map and estimate the coverage of the region, we digested them with rare-cutting enzymes and sized the fragments by PFGE. Because YAC DNA is not methylated, sites can be present in YACs but normally methylated and therefore not digested in human genomic DNA. When these sites are much more numerous in the YACs, as with 6-cutters such as NruI, BsiWI, and MluI, YAC maps can be difficult to order and comparisons between genomic and YAC maps can be problematic. Therefore the 8-cutter enzymes NotI and AscI were chosen for mapping because, in our experience, few cryptic YAC sites exist for these two enzymes. The locations of all 15 probes on the YAC fragments were confirmed by Southern blot hybridization of the PFGE gels. YACs that were either nonchimeric or that contained substantial segments of apparently unrearranged CES region are shown in Figure 4 compared with the NotI/ AscI PFGE map. The NotI and AscI fragments of YACs that appeared to be substantially chimeric by FISH did not fit the PFGE map of the CES region, confirming that the $\mathrm{FISH}$ results were not attributable to cross-hybridization with low copy repeated sequences present on other chromosomes but not blocked by the preannealing step. The order of ATP6E and D22S57 could not be determined from PFGE or YAC results, but had been determined previously (Mears et al. 1995). Of the three nonchimeric YACs, 803G9 shows a substantial internal deletion. This YAC is listed in Morrow et al. (1995) as $1390 \mathrm{~kb}$. We obtained isolates of this YAC from two different platings of the CEPH megaYAC library and regrew it numerous times. However, although the size varied dramatically with the isolate (Table 2 , footnotes), none was near the previously reported size.

There are two gaps in the YAC contig, one between D22S458 and D22S795, and one between D22S43 and ATP6E. Thus, over $1000 \mathrm{~kb}$ of the CES region has been cloned in YACs, most of it concentrated between D22S795 and D22S181.

\section{Localization of D22S111 Outside the CES Region}

Preliminary hybrid panel data indicated that D22S111 maps to the CES region, but the PFGE pattern of fragments for this locus does not match any region of the map (Fig. 1). A recent YAC contig map (Collins et al. 1995) places the STS of D22S111 at two sites: one between $\mathrm{D} 22 \mathrm{~S} 458$ and D22S50, in the proximal $1 \mathrm{Mb}$ of the CES region, and one adjacent to the gene HCF2, which maps to somatic cell hybrid bin 8.1 (Budarf et al. 1996). Therefore, FISH was performed, using the D22S111 cosmid N39C5, on CES patient metaphase spreads to resolve this discrepancy. The cosmid was isolated from the LL22NC03 library by hybridization to the D22S111 probe KI-197, and the presence of the probe was confirmed by hybridization. The presence of the D22S111 STS within the cosmid was confirmed by PCR. Using FISH the cosmid hybridized to the proximal region of the normal chromosome 22s, but did not hybridize to either the supernumerary ring chromosome that defines the CES critical region (Mears et al. 1995) or a typical CES bisatellited marker chromosome (CM11 from Mears et al. 1994) (data not shown). However, a second cosmid (N64E9), which maps slightly more proximal on the Collins YAC contig than D22S111, did hybridize to both the normal 22s and the CES chromosomes, as well as a D-group chromosome centromere (data not shown). Therefore, both PFGE and FISH analysis indicates that the D22S111 probe and cosmid N39C5 both map to the distal site in bin 8.1, whereas the D22S111 STS presumably detects a repeated sequence present in both bin 1 and bin 


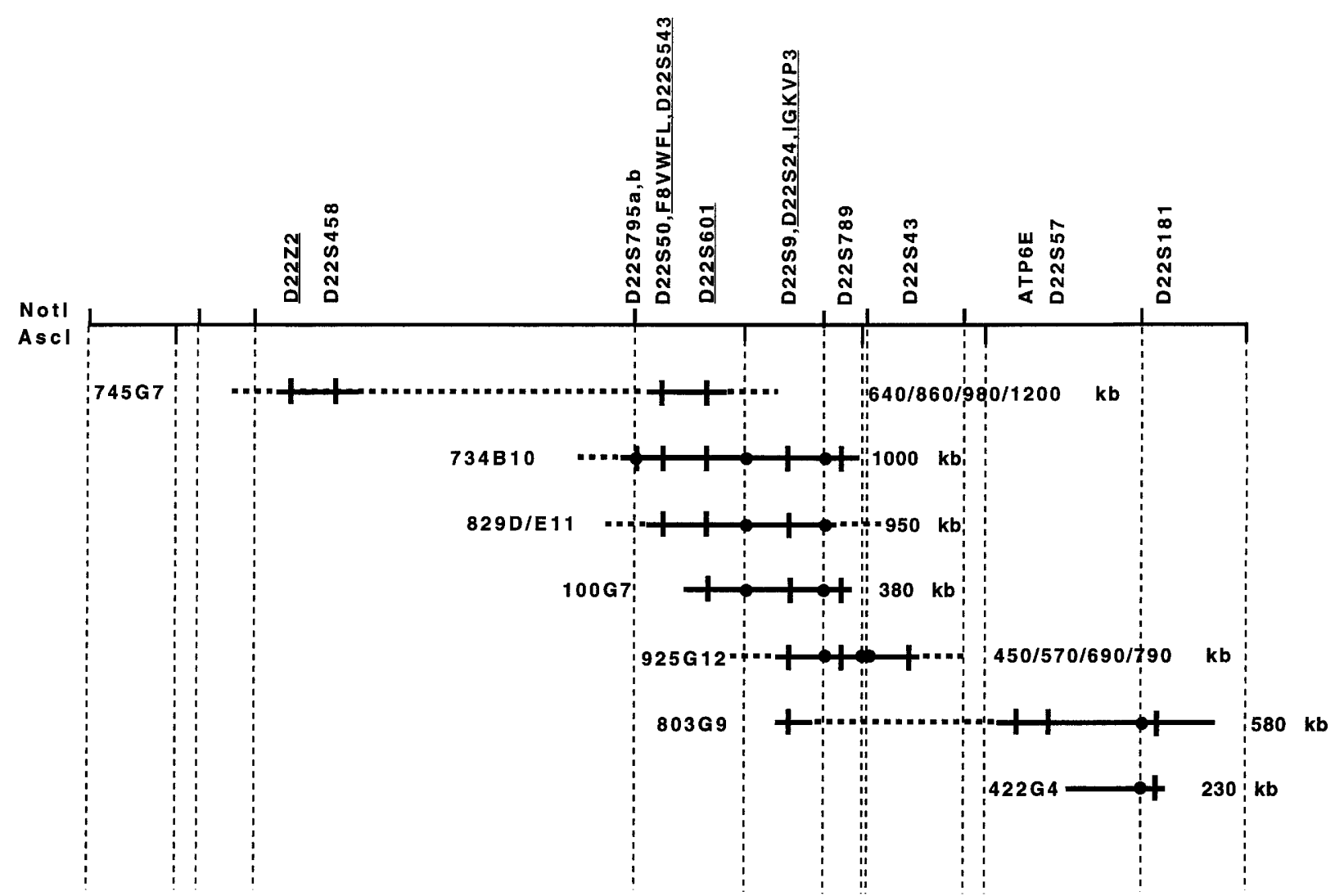

Figure 4 YAC contig within the CES critical region. The presence of probes on the YAC clones were identified by PCR analysis and Southern blot hybridization and are represented on the figure by a short vertical line through the YAC. Notl and Ascl sites mapped to each YAC are represented by dots, and the Notl/Ascl map is shown above the contig. The position of each locus is based on the PFGE map. Probes not analyzed by PFGE (underlined) were placed according to the YAC analysis. D22Z2 is an alpha-satellite probe known to be proximal to D22S458. It was placed on the map by virtue of its presence on YAC 745G7, which lacks the proximally placed Ascl and Notl sites. A dashed segment within the lines representing the YACs indicates the presence of a deletion. Dashed segments on the ends of the YAC lines indicate the start of a chimeric fragment, but if it is not known which end is contiguous with the chimeric DNA, both ends are indicated by dashed segments. YAC sizes were determined by PFGE and are listed to the right of each YAC.

8.1 as reported by Collins et al. (1995). The order of other probes on our PFGE map agrees with that of Collins et al. (1995).

\section{DISCUSSION}

We have produced a PFGE map of the CES region of $22 \mathrm{q} 11.2$ from the pericentromeric probe $\mathrm{N} 38 \mathrm{~F} 3$ to D22S36. This covers the region duplicated in a typical CES marker chromosome (Mears et al. 1994). The map covers a maximum distance of $\sim 3.6 \mathrm{Mb}$.

An unusual CES patient has been used previously to narrow the size of the CES critical region (Mears et al. 1995). This patient had all of the cardinal phenotypic features of CES, but cytoge- netic analysis revealed the presence of an unusually small supernumerary double ring chromosome 22 . By dosage analysis and FISH, this ring chromosome was shown to contain only the loci proximal to D22S57. Based on our PFGE map, we can conclude that the redefined critical region spans a maximum of only $1.9 \mathrm{Mb}$, all of which is present on one partially digested MluI fragment (Fig. 2).

After our initial YAC mapping had been completed, two other groups published larger YAC contigs that included the CES region (Collins et al. 1995; Morrow et al. 1995). Many YACs are common to all three maps. The order of the probes along the PFGE map is completely supported both by our PFGE-independent computer 
analysis of our STS-derived data using our 15 YACs and by the identical order (except for D22S111, explained above) found by Collins et al. (1995), who used all probes analyzed in our study except D22S795. Collins et al. (1995) were also able to distinguish order for D22S50/ F8VWFL/D22S543 and D22S9/D22S24/IGKVP3. Comparison with the Morrow et al. (1995) map is more difficult because many of the probes used in the two studies are different; however, the only discrepancy is the placement of D22S601 centromeric to F8VWFP and D22S543, which disagrees with both our map and that of Collins et al. (1995). All three maps also show deletions within YAC 745G7.

Our analysis of the integrity of the YACs indicated that most were prone to rearrangement and/or were chimeric. The multiple or variablesized bands seen in four YACs all hybridized to the expected probes in the CES region, confirming the instability of the YACs rather than the presence of multiple independent YACs. Mapping of the YACs with NotI and AscI supported the FISH results that all but three YACs were chimeric.

Two gaps exist in our YAC contig. The gap between D22S43 and ATP6E would probably be covered by a larger isolate of YAC 803G9, which is prone to deletion. This YAC is listed as $1390 \mathrm{~kb}$ in Morrow et al. (1995) and contains probes D22S9, D22S24, ATP6E, and D22S181. At 1390 $\mathrm{kb}$, this YAC appears too big for the CES region it covers and therefore may be chimeric. In Collins et al. (1995), 803G9 is unsized, but contains only IGKVP3 and D22S24 and not D22S9, D22S789, D22S43, ATP6E, D22S57, or D22S181.

The second gap between D22S548 and D22S795 is substantial. However, the relative lack of rare-cutting sites in this region and its proximity to the centromere indicates that it may be gene-poor. In addition, preliminary molecular analysis of an interstitial duplication patient manifesting some features of CES places the proximal limit of this duplication between D22S795 and D22S50 (A.J. Mears, K.E. McTaggart, and H.E. McDermid, unpubl.). For the features present in this patient (preauricular malformations, heart defect, kidney defect, and developmental delay; Knoll et al. 1995), the region of interest is further narrowed to no more than 1 $\mathrm{Mb}$ and includes only the smaller gap in the YAC contig.

Although over $1000 \mathrm{~kb}$ of the critical region appears to be contained within these YACs, their instability indicates that they should be used with caution to produce a finer cosmid/BAC/PAC contig, which is currently under way (H.E. McDermid and N. Shimizu, unpubl.). This PFGE map is proving to be an invaluable resource for producing this contig. These cosmid/BAC/PAC clones will be used as the basis for the development of a transcription map with the objective of identifying genes involved in CES. To date only one gene, ATP6E, has been mapped to the CES critical region (Baud et al. 1994). The isolation of additional genes over the $1.9-\mathrm{Mb}$ critical region will aid in understanding the pathophysiology of the syndrome.

\section{METHODS}

\section{Probes}

The probes used in the production of the long-range map and YAC contig are shown in Table 1. D22Z2 contains alpha-satellite DNA specific for chromosome 22 (McDermid et al. 1986b). N38F3 is a cosmid isolated by walking from cosmids containing alpha-satellite sequences and is therefore close to or within the centromere (Xie et al. 1994). The probe used is a $1.5-\mathrm{kb}$ HindIII fragment. N63 (locus D22S795) is a lambda phage clone isolated from a NotI half-linking library (McDermid et al. 1989). Probe LN63a (D22S795a), a 1.3-kb SmaI/EcoRI fragment, was used to isolate cosmid 127B8 from the LL22NC03 library. This cosmid contains the LN63 NotI site. Probe LN63b (D22S795b), a 1.9-kb SstI/NotI fragment, represents the other side of this NotI site. F8VWFL is an unprocessed pseudogene. For analysis of cosmids containing F8VWFL, a 3.2-kb EcoRI fragment of F8VWF (on chromosome 12), which cross-hybridizes to F8VWFL, was used (ATCC 59784). All cosmids were isolated from the LL22NC03 chromosome 22 -specific gridded cosmid library (de Jong et al. 1989).

\section{Pulsed-field Gel Electrophoresis}

PFGE was performed using a CHEF-DRII apparatus (BioRad). Conditions were as described previously (McDermid et al. 1993). DNA fragments larger than $1000 \mathrm{~kb}$ were sized using the chromosomes of Hansenula wingei (BioRad). DNA isolated from a number of cell lines was used in the analysis. Fibroblasts GM05565 and lymphoblastoid cell line GM03657 are both from normal individuals. One culture of GM03657 was treated with $2 \mu \mathrm{M}$ 5-azacytidine, a demethylating agent, for several weeks. Fresh normal kidney tissue (Bauer et al. 1993) and fresh normal lymphocytes were also used. A number of cell lines with chromosomal abnormalities known to be outside the CES region were examined in conjunction with the normal cells to compare presumed DNA methylation differences, although bands present in only one such cell line were discounted. These cell lines included GM02325 (fibroblasts with a partial trisomy attributable to the karyotype 47 , $X X,+\operatorname{der}(22) t(16 ; 22)(p 13.3 ; q 12.2)$; Sutherland et al. 


\section{LONG-RANGE MAP AND YAC CONIIG FOR CAT EYE SYNDROME}

1989), GM07511A (fibroblasts containing a balanced translocation with a breakpoint in the IGL locus; H.E. McDermid and M.A. Riazi, unpubl.), BL-2 (a Burkitt lymphoma cell line containing a $t(8 ; 22)$ with the breakpoint in the IGL locus; Croce et al. 1983), two Ewing sarcoma tumor cell lines [TC32 (Griffen et al. 1986) and TW (Budarf et al. 1989)], and two lymphoblastoid cell lines with 22q13.3 deletions (JT and AJ; Nesslinger et al. 1994). All fibroblasts or cell lines beginning with " $\mathrm{GM}^{\prime}$ " were obtained from the Human Genetic Mutant Cell Repository, Camden, NJ.

\section{Southern Blot Analysis}

DNA in PFGE gels were transferred to nylon membrane (GeneScreen Plus, DuPont) by Southern blotting or vacuum-blotting, hybridized, and washed as described previously (McDermid et al. 1993). Probes were labeled by the random primer technique (Feinberg and Vogelstein 1984). A number of probes were prehybridized with sheared placental DNA to block repetitive sequences present in the fragment (Litt and White 1985). Many PFGE blots were probed, stripped, and reprobed up to 20 times to allow superimposition of the bands during analysis. Autoradiographs were aligned by including in the hybridization reaction radioactive wild-type lambda that visualized the lambda concatamer control lanes.

\section{Screening of YAC Libraries}

Screening of the libraries was done by PCR on yeast DNAs pooled in two and three dimensions as described previously (Bell et al. 1995). The STSs (with accession no.) used are as follows: D22S458 (Genome Data Base:4073017), D22S543 (GDB:335911), D22S601 (GDB:335948), D22S9 (GDB:270278), D22S24 (GDB:270283), D22S789 (GDB: 4073026), ATP6E (GDB:4073032), D22S57 (GDB:372457), and D22S181 (GDB:4073034). STSs for D22S458, D22S789, ATP6E, and D22S181 were reported previously in Budarf et al. (1996). Four STSs were developed specifically for this project: D22S795 (AGGATCAAGGTCTCCTAGCATG/ TGCGGTGAGCCAAGATTATG, 232 bp, GDB:4073020), D22S50 (AAAGTGCTAGAGGAGTTCGGG/TTCATAGTCCATTGTGCAAATT, 283 bp, GDB:4073022), IGKVP3 (GGCTCCTCATCCATGGTG/GAGGTTTGGTTTCCT GTGGA, 183 bp, GDB:4073024), and D22S43 (GCCTGACAAGGACCTGCAGTCCTCT/AAGAGGAGC TAATTTTCACATC, 111 bp, GDB:4073029). Primers were selected using the PRIMER program (E.S. Lander, Whitehead Institute) and synthesized by Research Genetics (Huntsville, AL) or Keystone Laboratories (Menlo Park, CA). The results of the library screens were confirmed by individual PCR reactions performed on purified yeast DNA or on single yeast colonies. Additional PCR reactions were performed on panels of YACs that were suspected to contain STSs, on the basis of the PFGE map. PCR results were confirmed by hybridization on Southern blots. YAC colonies were cultured for two days, after which DNA was extracted, digested with HindIII, electrophoresed (standard and PFGE), blotted, and hybridized consecutively to each probe. Multiple isolates for YACs $803 \mathrm{G} 9$ and 745G9 were obtained from two different copies of the CEPH megaYAC library, one in our lab (Children's Hospital of Philadelphia) and one at the CGAT Large-Insert Library Screening
Facility, The Hospital for Sick Children, Toronto, Ontario, Canada.

\section{End Cloning of YAC 734B10}

Genomic DNA from yeast clones containing YAC 734B10 was digested separately with HindIII and TaqI, which digest in the right and left arm of the YAC vector, respectively (the left arm contains the centromere), and at unknown sites in the genomic DNA insert (Arveiler and Porteous 1991). The junction fragments, containing the cloning site flanked on one side by vector DNA and by insert on the other, were circularized by ligating the digested YAC DNA under conditions of low DNA concentration. Small aliquots of the ligated DNA (containing $<1 \mathrm{ng}$ DNA) were then amplified with left or right arm-specific primer pairs (AAACTCAACGAGCTGGACGC and GCCCGATCTCAAGATTACG for HindIII-digested samples, TTTCACTCTGAACCATCTTGGAAGGACCGG and GAATTGATCCACAGGACGGG for the TaqI-digested samples), the members of each pair oriented 3' to 3 ' relative to each other following circularization. The HindIII- or TaqIdigested samples were designated 734B10T and $734 \mathrm{~B} 10 \mathrm{HU}$, respectively. A hot-start protocol was employed using Boehringer Mannheim Expand PCR kit cocktail and a primer annealing temperature of $60^{\circ} \mathrm{C}$. The amplified DNA fragments were analyzed by agarose gel electrophoresis and labeled using the random hexamer method to generate radioactive hybridization probes. The location of each end clone was confirmed by hybridization to YACs or to the monochromosomal somatic cell hybrid mapping panel \#2 from the NIGMS Human Genetic Mutant Cell Repository.

\section{FISH}

FISH was used to test for YAC chimerism. Total DNA (2-3 $\mu \mathrm{g})$ from YAC-containing yeast lines was labeled using the Bionick Labeling System (BRL). The reaction was allowed to proceed until fragment sizes optimal for FISH $(<800 \mathrm{bp})$ were obtained (confirmed by agarose gel electrophoresis). Biotinylated DNA was then combined with 10-20 $\mu \mathrm{g}$ Cot-1 DNA (BRL) and 10-20 $\mu$ g sonicated herring sperm DNA, precipitated, and resuspended at $37^{\circ} \mathrm{C}$ overnight in a $50 \%$ formamide, $2 \times$ SSC, $20 \%$ dextran sulfate hybridization solution. This probe mixture was denatured at $75-80^{\circ} \mathrm{C}$ for 5 min and then allowed to partially preanneal at $37^{\circ} \mathrm{C}$ for a maximum of $1.5 \mathrm{hr}$ (Lichter et al. 1988).

Metaphase spreads were prepared from CES cell lines CM11 (Mears et al. 1994) and CM15 (Mears et al. 1995). Because the chromosomes were not banded, hybridization to the CES chromosome would confirm probe localization to that region. Slides were treated with RNase and denatured as described in the ONCOR manual. The hybridization solution was then added to the prewarmed slides, covered with a glass coverslip, sealed with rubber cement, and incubated at $37^{\circ} \mathrm{C}$ for $18 \mathrm{hr}$ in a humidifying chamber. Posthybridization washes were performed at $42-45^{\circ} \mathrm{C}$ as described in Kuwano et al. (1991), with the following modifications: $15 \mathrm{~min}$ in 50\% formamide and $2 \times$ SSC, 15 min in $50 \%$ formamide and $1 \times$ SSC, $2 \times 10 \mathrm{~min}$ in $1 \times$ SSC. This was followed by washes at room temperature: $5 \mathrm{~min}$ in $0.1 \times \mathrm{SSC}$ and $2 \mathrm{~min}$ in $1 \times \mathrm{PBD}$ (ONCOR). 


\section{McDERMID EI AL.}

Detection and amplification were as described in the ONCOR manual, except the blocking reagent 1 was a $3 \%$ bovine serum albumin (BSA) $(\mathrm{BRL}) / 4 \times \mathrm{SSC}$ solution and blocking reagent 2 was $1 / 10$ goat serum (Sigma) $/ 4 \times$ SSC. The washes following the avidin and antiavidin incubations consisted of $1 \times 10 \mathrm{~min}$ and $2 \times 5 \mathrm{~min}$ at $45-48^{\circ} \mathrm{C}$. Metaphase spreads were counterstained with propidium iodide (ONCOR) and examined using a Zeiss Axiophot photomicroscope with a Zeiss 9 filter. Spreads were photographed using Kodak Ektachrome Elite 100 color slide film.

FISH was also performed using the D22S111 cosmid N39C5 and cosmid N64E9 on CES cell lines. FISH with cosmids was performed as above except 1-2 $\mu \mathrm{g}$ cosmid DNA was labeled for 1-2 hr with the Bionick Labeling System (BRL), and Cot-1 DNA was the only competitor DNA used in the preparation of probes for hybridization.

\section{ACKNOWLEDGMENTS}

We thank Drs. Y.-G. Xie, J. Dumanski, G. Rouleau, M. Lipinski, and E. Zwarthoff for providing us with probes, Dr. David Searls for the use of his contig construction program, Dr. B. Barnoski for helpful suggestions regarding YAC FISH, and Karen Romanyk, Dana Shkolny, Angela Johnson, and Roy Johanson for technical assistance. Some YAC isolates were kindly provided by Ms. Sylvia Soder at the CGAT Large-Insert Library Screening Facility, The Hospital for Sick Children, Toronto. This work was supported by a grant from the Medical Research Council of Canada (H.E.M.) and by National Institutes of Health/National Center for Human Genome Research grants P50-HG00425 (B.S.E., M.L.B., C.J.B.) and P50-HG00098 (T.J.H.).

The publication costs of this article were defrayed in part by payment of page charges. This article must therefore by hereby marked "advertisement" in accordance with 18 USC section 1734 solely to indicate this fact.

\section{REFERENCES}

Albertsen, H.M., H. Abderrahim, H.M. Cann, J. Dausset, D. Le Paslier, and D. Cohen. 1990. Construction and characterization of a yeast artificial chromosome library containing seven haploid human genome equivalents. Proc. Natl. Acad. Sci. 87: 4256-4260.

Arveiler, B. and Porteous, D.J. 1991. Amplification of end fragments of YAC recombinants by inverse-polymerase chain reaction. Technique 3: 24-28.

Baud, V., A.J. Mears, V. Lamour, C. Scamps, A.M.V. Duncan, H.E. McDermid, and M. Lipinski. 1994. The E subunit of vacuolar $\mathrm{H}^{+}$-ATPase localizes close to the centromere on human chromosome 22. Hum. Mol. Genet. 3: 335-339.

Bauer, T.R., Jr., H.E. McDermid, M.L. Budarf, M.L. Van Keuren, and B.B. Blomberg. 1993. Physical location of the human immunoglobulin lambda-like genes, 14.1, 16.1, and 16.2. Immunogenetics 38: 387-399.

Bell, C.J., M.L. Budarf, B.W. Nieuwenhuijsen, B. Barnoski, K.H. Buetow, K. Campbell, A. Colbert, J.
Collins, P.R. Desjardins, T. DeZwaan, B. Eckman, S. Foote, K. Hart, K. Hiester, M.J. Van Het Hoog, E. Hopper, A. Kaufman, H.E. McDermid, G.C. Overton, M.P. Reeves, D.B. Searls, L. Stein, V.H. Valmiki, E. Watson, S. Williams, R. Winston, R.L. Nussbaum, E.S. Lander, K.H. Fischbeck, B.S. Emanuel, and T.J. Hudson. 1995. Integration of physical, breakpoint and genetic maps of chromosome 22 . Localization of 587 yeast artificial chromosomes with 238 mapped markers. Hum. Mol. Genet. 4: 59-69.

Budarf, M., B. Sellinger, C. Griffen, and B.S. Emanuel. 1989. Comparative mapping of the constitutional and tumor associated 11;22 translocations. Am. J. Hum. Genet. 45: 128-139.

Budarf, M.L., H. McDermid, B. Sellinger, and B.S. Emanuel. 1991. Isolation and regional localization of 35 unique anonymous DNA markers for human chromosome 22. Genomics 10: 996-1002.

Budarf, M.L., B. Eckman, D. Michaud, T. McDonald, S. Gavigan, K.H. Buetow, Y. Tatsunura, Z. Lui, C. Hilliard, E. Goldmuntz, E. Meese, E.C. Zwarthoff, S. Williams, H. McDermid, J.P. Dumanski, J. Biegel, C.J. Bell, and B.S. Emanuel. 1996. Regional localization of over 300 loci on human chromosome 22 using a somatic cell hybrid mapping panel. Genomics 35: 275-288.

Carey, A.H., S. Roach, R. Williamson, J.P. Dumanski, M. Nordenskjold, V.P. Collins, G. Rouleau, N. Blin, P. Jalbert, and P.J. Scambler. 1990. Localization of 27 DNA markers to the region of human chromosome 22q11-pter deleted in patients with the DiGeorge syndrome and duplicated in the der22 syndrome. Genomics 7: 299-306.

Chumakov, I., P. Rigault, S. Guillou, P. Ougen, A. Billaut, G. Guasconi, P. Gervy, I. Le Gall, P. Soularue, L. Grinas, et al. 1992. Continuum of overlapping clones spanning the entire human chromosome 21q. Nature 359: $380-387$.

Collins, J.E., C.G. Cole, L.J. Smink, C.L. Garrett, M.A. Leversha, C.A. Soderlund, G.L. Maslen, L.A. Everett, K.M. Rice, A.J. Coffey, S.G. Gregory, R. Gwilliam, A. Dunham, A.F. Davies, S. Hassock, C.M. Todd, H. Lehrach, T.J.M. Hulsebos, J. Weissenbach, B. Morrow, R.J. Kucherlapati, R. Wadey, P.J. Scambler, U.-J. Kim, M.I. Simon, M. Peyrard, Y.-G. Xie, N.P. Carter, R. Durbin, J.P. Dumanski, D.R. Bentley, and I. Dunham. 1995. A high-density YAC contig map of human chromosome 22. Nature (Suppl.) 377: $367-379$.

Croce, C.M., W. Thierfelder, J. Erikson, K. Nishikura, J. Finan, G.M. Lenoir, and P.C. Nowell. 1983. Transcriptional activation of an unrearranged and untranslocated c-myc oncogene by translocation of a $C \lambda$ locus in Burkitt lymphoma cells. Proc. Natl. Acad. Sci. 80: $6922-6926$.

de Jong, P.J., K. Yokobata, C. Chen, F. Lohman, L. Pederson, J. McNinch, and M. Van Dilla. 1989. Human chromosome-specific partial digest libraries in lambda and cosmid vectors. Cytogenet. Cell Genet. 51: 985.

Driscoll, D.A., M.L. Budarf, and B.S. Emanuel. 1992. A genetic etiology for DiGeorge syndrome: Consistent deletions and microdeletions of 22q11. Am. J. Hum. Genet. 50: 924-933. 


\section{LONG-RANGE MAP AND YAC CONIIG FOR CAT EYE SYNDROME}

Feinberg, W.J. and B. Vogelstein. 1984. A technique for radiolabeling DNA restriction fragments to high specific activity. Anal. Biochem. 137: 266-267.

Griffen, C.A., C. McKeon, M.A. Israel, A. Gegonne, J. Ghysdael, D. Stehelin, E.C. Douglass, A.A. Green, and B.S. Emanuel. 1986. Comparison of constitutional and tumor-associated 11;22 translocations: Nonidentical breakpoints on chromosomes 11 and 22. Proc. Natl. Acad. Sci. 83: 6122-6126.

Hudson, T.J., A.M.E. Colbert, M.P. Reeve, J.S. Bae, M.K. Lee, R.L. Nussbaum, M.L. Budarf, B.E. Emanuel, and S. Foote. 1994. Isolation and regional mapping of 110 chromosome 22 STSs. Genomics 24: 588-592.

Knoll, J.H.M., A. Asamoah, B.A. Pletcher, and J. Wagstaff. 1995. Interstitial duplication of proximal 22q: Phenotypic overlap with cat eye syndrome. Am. J. Med. Genet. 55: 221-224.

Kuwano, A., S.A. Ledbetter, W.B. Dobyns, B.S. Emanuel, and D.H. Ledbetter. 1991. Detection of deletions and cryptic translocations in Miller-Dieker syndrome by in situ hybridization. Am. J. Hum. Genet. 49: 707-714.

Lekanne Deprez, R.H., N.A. van Biezen, P. Heutink, K.R.G.S. Boejharat, A. de Klein, A.H.M. Guerts van Kessel, and E.C. Zwarthoff. 1991. A new polymorphic probe on chromosome 22: NB17 (D22S181). Nucleic Acids Res. 19: 686.

Lichter, P., T. Cremer, J. Borden, L. Manuelidis, and D.C. Ward. 1988. Delineation of individual human chromosomes in metaphase and interphase cells by in situ suppression hybridization using recombinant DNA libraries. Hum. Genet. 80: 224-234.

Litt, M. and R. White. 1985. A highly polymorphic locus in human DNA revealed by cosmid derived probes. Proc. Natl. Acad. Sci. 82: 6206-6210.

Lotscher, E., K.-H. Grzeschik, H.G. Bauer, H.-D. Pohlenz, B. Straubinger, and H.G. Zachau. 1986. Dispersed human immunoglobulin $\kappa$ light-chain genes. Nature

320: $456-458$.

McDermid, H.E., A.M.V. Duncan, K.R. Brasch, J.J.A. Holden, E. Magenis, R. Sheehy, J. Burn, N. Kardon, B. Noel, A. Schinzel, I. Teshima, and B.N. White. 1986a. Characterization of the supernumerary chromosome in cat eye syndrome. Science 232: 646-648.

McDermid, H.E., A.M.V. Duncan, M.J. Higgins, J.L. Hamerton, E. Rector, K.R. Brasch, and B.N. White. 1986b. Isolation and characterization of an $\alpha$-satellite repeated sequence from human chromosome 22 . Chromosoma 94: 228-234.

McDermid, H.E., M.L. Budarf, and B.S. Emanuel. 1989. Toward a long-range map of human chromosomal band 22q11. Genomics 5: 1-8.

McDermid, H.E., M.L. Budarf, and B.S. Emanuel. 1993.
Long-range map of human chromosome 22q11-22q12 between the lambda immunoglobulin locus and the Ewing sarcoma breakpoint. Genomics 18: 308-318.

Mancuso, D.J., E.A. Tuley, L.A. Westfield, T.L. Lester-Mancuso, M.M. Le Beau, J.M. Sorace, and J.E. Sadler. 1991. Human von Willebrand factor gene and pseudogene: Structural analysis and differentiation by polymerase chain reaction. Biochemistry 30: 253-269.

Mears, A.J., A.M.V. Duncan, M.L. Budarf, B.S. Emanuel, B. Sellinger, J. Siegel-Bartelt, C.R. Greenberg, and H.E. McDermid. 1994. Molecular characterization of the critical region of cat eye syndrome. Am. J. Hum. Genet. 55: 134-142.

Mears, A.J., H. El-Shanti, J.C. Murray, H.E. McDermid, and S.R. Patil. 1995. Minute supernumerary ring chromosome 22 associated with cat eye syndrome: Further delineation of the critical region. Am. J. Hum. Genet. 57: 667-673.

Morrow, B., R. Goldberg, C. Carlson, R. Das Gupta, H. Sirotkin, J. Collins, I. Dunham, H. O'Donnell, P. Scambler, R. Shprintzen, and R. Kucherlapati. 1995. Molecular definition of the 22q11 deletions in velo-cardio-facil syndrome. Am. J. Hum. Genet. 56: 1391-1403.

Nesslinger, N.J., J. Gorski, T.W. Kurczynski, S.K. Shapira, J. Siegel-Bartelt, J.P. Dumanski, R.F. Cullen Jr., B.N. French, and H.E. McDermid. 1994. Clinical, cytogenetic and molecular characterization of seven patients with deletions of chromosome 22q13.3. Am. J. Hum. Genet. 54: $464-472$.

Reiss, J.A., R.G. Weleber, M.G. Brown, C.D. Bangs, E.W. Lovrien, and R.E. Magenis. 1985. Tandem duplication of proximal 22q: A cause of cat eye syndrome. Am. J. Med. Genet. 20: 165-171.

Rouleau, G.A., J.L. Haines, A. Bazanowski, C.A. Colella, J.A. Trofatter, N.S. Wexler, P.M. Conneally, and J.F. Gusella. 1989. A genetic linkage map of the long arm of human chromosome 22. Genomics 4: 1-6.

Schinzel, A., W. Schmid, M. Fraccaro, L. Tiepolo, O. Zuffardi, J.M. Opitz, J. Lindsten, P. Zetterqvist, H. Enell, C. Baccichetti, R. Tenconi, and R.A. Pagon. 1981. The "cat eye syndrome": Dicentric small marker chromosome probably derived from a no. 22 (Tetrasomy 22 pter $\rightarrow$ q11) associated with a characteristic phenotype. Hum. Genet. 57: 148-158.

Sutherland, G.R., E. Baker, V.J. Hyland, D.F. Callen, J. Stahl, and N.M. Gough. 1989. The gene for human leukemia inhibitory factor (LIF) maps to 22q12. Leukemia 3: 9-13.

Xie, Y.-G., F.-Y. Han, S. Bajalica, E. Blennow, U. Kristoffersson, J.P. Dumanski, and M. Nordenskjold. 1994. Identification, characterization and clinical applications of cosmids from the telomeric and centromeric regions of the long arm of chromosome 22. Hum. Genet. 94: 339-345.

Received May 29, 1996; accepted in revised form October 23, 1996. 


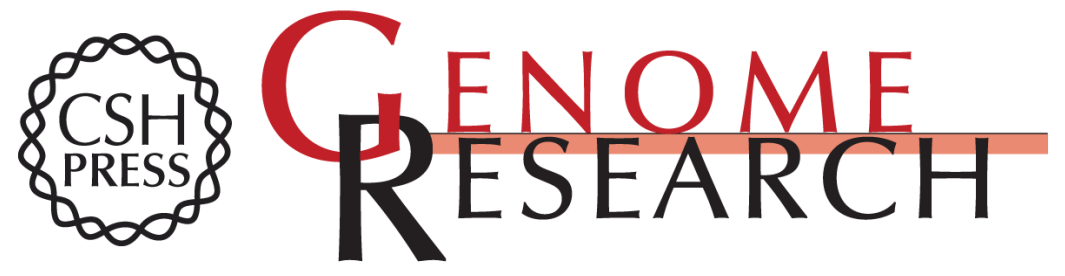

\section{Long-range mapping and construction of a YAC contig within the cat eye syndrome critical region.}

H E McDermid, K E McTaggart, M A Riazi, et al.

Genome Res. 1996 6: 1149-1159

Access the most recent version at doi:10.1101/gr.6.12.1149

References This article cites 36 articles, 5 of which can be accessed free at:

http://genome.cshlp.org/content/6/12/1149.full.html\#ref-list-1

\section{License}

Email Alerting Receive free email alerts when new articles cite this article - sign up in the box at the Service top right corner of the article or click here.

\section{Affordable, Accurate Sequencing.}

To subscribe to Genome Research go to: https://genome.cshlp.org/subscriptions 